\title{
THE EFFECT OF GENERAL ANAESTHESIA ON THE SEROTONIN LEVELS IN BRAIN, BLOOD, KIDNEY AND SMALL INTESTINE OF THE EXPERIMENT AL ANIMALS
}

\author{
By F.H. Mansy. M.D., M.A. Abdel-Hameed. M.D. \& Abdel-Azeez Hamed. M.D. \\ (From Departments of Pharmacology \& Anaesthesia, Faculty of Medicine, Tanta University. Egypt)
}

\section{INTRODUCTION:}

Scrotonin (5-hydroxy? ryptamine) is an aclive a mine which is actually locally synzhesiced in tissues rather than transmitted from one organ to the other. It is a potens vasoconstrictor agenı and smooth muscle stimulant. "l caures an increase in peripheral vascular resistance as ivell as coronary vasospasm (Goodman and Gillman. 1976).

5-hydroxytryplamine (5-HT) has a complex accion on blood pressure. Itsaction starts by a briel depressor phasic. probably duc 10 coronary chemoreflex: followed by a pressor phase due 10 its direct action. Finally it has a depressor phase due lo direct dilator aclion.

The action of serolonin on the central nervous system was studied on animals, and it was found to cause some dizzincss with a variety of stimulant and depressant actions causes of which are uncertain (Goodnan and Gillman. 1976). It has a stimulant action on peripheral nerves. Sherwood (1954) found that S-HT, produced muscle weakness when injected intraventricularly. Animals in his experiment altaincd a sleeping posture with some degrec of calalonia. Cur is \& David (1962) found that 5-HT blocked transmission through the lateral geniculate nucleus.

Lida Swafford (1966) found that serotonin had a direct relation to stress conditions. Serotonin level was elevaled in the blood in pulmonary embolism. Alsu serotonin experimentally produced pulmonary artery hypertension. Anderson \& Bonnycastle (1960) and Bonnycasle et al (1962) observed an increase of the level of brain serotonin during anesthesia witly erher and other central nervous system depressants. Neffet al (1967) and Diaz el al (1968) found an increase of cerebral serotonin level in animals during anaesthesia using different anaesthetics. Lida Swafford (1966) postulated a direcl relationship between general anaestlicsia and the level of serolonin in blood ano she suggested that the use of antiserotonin agenis prophylactically during general anaesıhesia might result in reduction of the incidence of such complications.

In the present work we planned 10 subject experimental animals (rabbis) to four different types of inhalation anaesthesia using. ether. halothane, trilene and chloroform and estimate the serotonin level in blood, brain. kidncys and small intestine during both the excitarory as well as the surgical stages of ancsihesia. We rimed to establish a relationship between libe serotonin level and the state of anaesthesia and to observe varialions between the different uypes of general inhalation anaestherics.

\section{MATERIAL AND METHODS:}

Aninals used:

I- Male albino rabbits weighing berween 1.5 and 2 $\mathrm{Kg}$. were subjected to general anacsthesia by inhalation after at fasting period of 12 hours. Eighl groups of animals were used; two groups for each of

TABLE 1. EFFELT OF DIETHYLETHER, HALUIHANE AND TRILENE ARAESTHESIA ON THE LEVELS OF SEROTONIN IN BRAIN, BLOOD, KIDNEY \& SMALL INTESTINE AT THE EXCITATORY/ STAGE AND AT AFTER 30 MIN OF SURGICAL STAGE

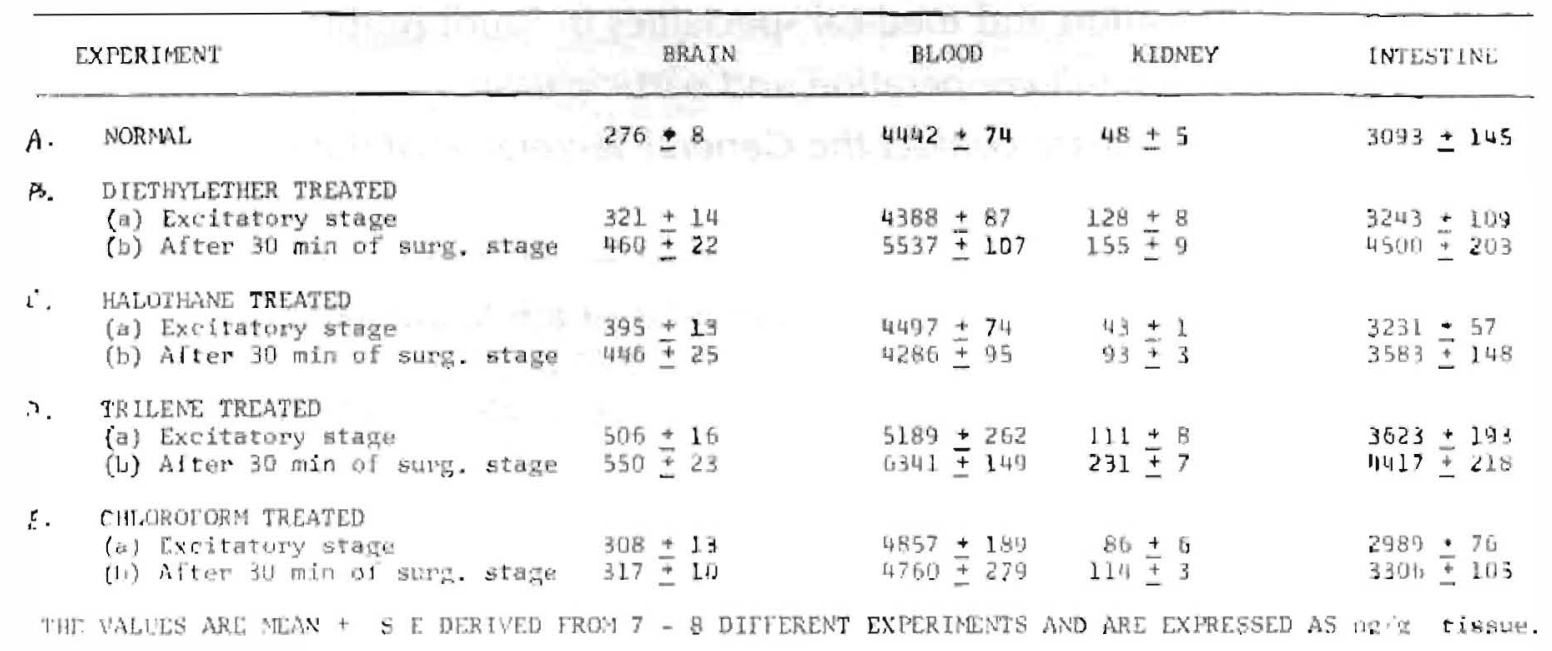


Tuble (2) Lerect or diethyl efior anaieshoaln at the excitutory deture on eerotonin level in rubolts tisgue日, brata, blood, klaneys and Houll inteatine in num/ em.

\begin{tabular}{|c|c|c|c|c|}
\hline No. & Brafo & blood & Kluneyg & Int eer lno \\
\hline 1 & 375 & 4720 & 170 & 3600 \\
\hline 2 & 350 & 4560 & 100 & 3100 \\
\hline 3 & 300 & 4200 & 125 & 3000 \\
\hline 4 & 275 & 4400 & L's & 3500 \\
\hline 5 & 300 & $\therefore 1.1$ & 125 & 2900 \\
\hline 6 & 300 & 4200 & I35 & 3600 \\
\hline 7 & 350 & 4600 & II5 & 3400 \\
\hline Waan & 321.4 & 4383.57 & 127.86 & $3242.60^{\circ}$ \\
\hline 8. E. & =13.83 & \pm 87.48 & $=8.25$ & $=108.79$ \\
\hline Y. D. & .36 .59 & $=231.47$ & $: 21.57$ & \pm 267.85 \\
\hline S. & $=2.77$ & 10.469 & \pm 0.36 & $=0.891$ \\
\hline$r$. & $<0.05$ & $>0.05$ & $<0.05$ & $>0.05$ \\
\hline
\end{tabular}

kesultb comphred with contron uroup (table). fuble(3) dithe effoct or dietiny eflyI ether anuonthesia ufter $30 \mathrm{~min}$ or auritcal stace on the aerotonla Ievel in rabbits tissueo, brain, blood

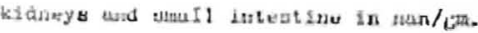

\begin{tabular}{|c|c|c|c|c|}
\hline 110. & birnin & 8:00d & X1dney & Litest \\
\hline I & Jus & snues & 90 & 4220 \\
\hline 2 & SUD & 5640 & 135 & 4000 \\
\hline 3 & 494 & 5400 & $I 35$ & 4360 \\
\hline 4 & usis & 5600 & 125 & SWOU \\
\hline 5 & AUU & 6100 & 90 & 56000 \\
\hline$\delta$ & 440 & 5360 & 9054 & 4300 \\
\hline 8 & 400 & 5260 & Ito & 4480 \\
\hline 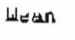 & 400 & 5537.14 & 155 & 4500 \\
\hline S. 2 . & 42.2 .36 & $\pm I U B .50$ & $\approx B .99$ & 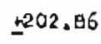 \\
\hline ¿. 10. & $=5 \% .16$ & $\pm 2,119.99$ & -23.8 & $=536.78$ \\
\hline $\mathrm{T}$ & $=7.6913$ & $14 \cdot \sqrt{25}$ & \pm 6.489 & \pm 5.627 \\
\hline$r$ & $<0.05$ & $<0.05$ & 0.05 & $<0.05$ \\
\hline
\end{tabular}

Wuan valuea eouptred wath conirol iroup (tablaI).
'Fable (4) Lrfeot of halotiune anaeacheara at the exo15ntury atace on ske aurocousn leveI

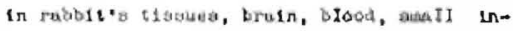
teatine * kilneys 1:i nan/etil.

\begin{tabular}{|c|c|c|c|c|}
\hline I10. & Gro1n & Heod & Kudroy & Intoutice \\
\hline 1 & 325 & 4720 & 56 & 3200 \\
\hline$P$ & $3^{\prime} x 0$ & 4320 & 40 & 3124 \\
\hline 3 & 290 & 4560 & it & 3220 \\
\hline 4 & 420 & 4760 & 15 & 3 you \\
\hline$\because$ & 430 & 4430 & 40 & 3.440 \\
\hline i & 410 & 4240 & $\Delta s$ & 3400 \\
\hline$y$ & 400 & 4400 & 45 & 3040 \\
\hline Secod & 395 & $4197.1 ;$ & 42.56 & 3231.13 \\
\hline 3.2. & 412.95 & \pm 73.30 & 11.43 & 257.54 \\
\hline ت. s, & $\therefore 31.28$ & $: 195.76$ & .3 .33 & $=152.25$ \\
\hline $\mathrm{I}$. & $\mathbf{2}^{7.725}$ & $=0.521$ & נו' & $=0.877$ \\
\hline P. & $<0.05$ & $>0.05$ & $>0.0$ & $>0.05$ \\
\hline
\end{tabular}

Fiste (5) The erfect of helothuge auneatbesid. errar jo atn of the surelcat atake, on berotondn Ievel in rublit a tianea,brusn, blood, ladeyg and amaIl foteatine, in naviga.

\begin{tabular}{|c|c|c|c|c|}
\hline No. & brain & bIoad & Krdney & Intest ino \\
\hline$I$ & 550 & $4 I 60$ & so & +220 \\
\hline 2 & 510 & $\therefore 4+0$ & 95 & 4000 \\
\hline 3 & 150 & 4210 & 110 & 3400 \\
\hline 4 & 380 & 4360 & 90 & $J \$ 40$ \\
\hline 5 & 450 & 1480 & Bs & 3160 \\
\hline 6 & 380 & 4520 & 90 & 3800 \\
\hline i & טاOي & 3000 & 90 & 3160 \\
\hline Yoan & 445.71 & 4285.71 & 92.86 & 3582.06 \\
\hline s. E. & $\$ 24.77$ & $\$ 94.50$ & 23.06 & $=140.00$ \\
\hline S. D. & $=0.54$ & $=25.26$ & \pm 6.49 & .341 .82 \\
\hline$T$. & $\$ 6 .: 17$ & \pm 1.30 & $\div 7.75$ & $=2.33$ \\
\hline 8. & $<0.05$ & $>0.05$ & $<0.05$ & $\leq 0.05$ \\
\hline
\end{tabular}


the general anacsiheric used. diethyl ether, halouhane, trilene and chlorolorm: lor each drug, a group of animals was cxanribed durng lac cxcitatory stage and the other during the surgical stage of andesthesia. A ninth group was examincd as control.

2-Albino rats ol cilber sex weighing 100 and $150 \mathrm{gm}$. were used for bioassay of the level of sefotonin in various lissues. Animals were kept separate and fasted for 24 hours. then ilsy were sacrificed and a hongindinal strip of the gastric lundus was remov'us and placed in an organ bath lor bioassay.

\section{INDUCTION OF GENERAI. INHALATION ANAESTHFSIA:}

Elher $w_{i l s}$ applied in a concentration of $4 \%$ and halothane was used in a concentration of $0.75 \%$. Each of these drugs was usted h! EMO apparatus. On the other hand trilene and chlordorm were applied using a mask by open melked. Ribbits were nbserved till they reached the reyured stage of anaesthesia. Animal was then sacriticed and samples of brain. kidney. small intestins and blood were taken separately for assay.

\section{EXTRACIION OF SEROTONIN FROM TISSUES:}

Each tissue was scparated. washed, homogenized (using a incalsured ciuanury of acelone 959), and then macerated for one hour al room temperature. The subsiance was then filtered wice through Whatman No. I lifler. The residue was then dried and suspended in a measured a mount of xaline fir bioassay.

One ml. of blood was mixed with one ml. ol distlled water ard $38 \mathrm{ml}$. of acerone and shaken well 10 bc hacmolysed. The hacmolysed material was macerated. filered and exiracted as helore (Amine el al. 19:54).

\section{BIOLOGICAI. ASSAY OF SEROTONIN IN RABBITS TISSUES:}

The method dencribed by Vane (1957) and impreved by Uuspaa (1962) using the lat lindal sirip preparation was used. A longiludinal muscle strip was separated from the rat gastric lundus and stretched in the organ bath ( $\operatorname{Lin} \&$ Yeoll. 1965). The maximal stretch of the longizudinal muscle sirip was ohatined for best sensitivity (Offermier \& Aricns. 1966). This was bathed in magnesium frec Kreb's solution with ample flow of air for oxygenation.

Each tissue exiract was assayed against standaró serotonin solution. Results wire recorded on i moving drum.

\section{RESULTS}

In the present work we estimated the serotonin levels in the brain, blood, kidney and small incestinc of animals induced with ether, halothane. trilenc or chloroform; both during the excitatory statc and during the stage of surgical anaesthesia.
Using diethyl elher as anaestluesia. The mean seroconin level in lhe brain showed a rise from 276.875 ng/g. in the normal control group 10 levels of 321.4 and $460 \mathrm{ng} / \mathrm{g}$. during the excitatory and surgical stages respectively (Table 1 and Fig. I) Halothane, on the other had resulted in lesser increase 10 level of 395 and $445.71 \mathrm{ng} / \mathrm{g}$. during above nentioned stages respectivelu. The most dramatic rise was encountered during the use of trilene as a general andexthetic when the brain levels of serolonin rose in 505.71 and $550 \mathrm{ng}$ g. in the iwo stages ol andest hesia respectroly. The chlorolorn caused a very slight increase of serotomin level in the brain as lle mean levels in both sliges of anacsibesia were 307.86 and $317.14 \mathrm{ng} / \mathrm{g}$.

By studyme the changes in serotonin kevel in the blood in horly stages nf a nacsibesia using each of the linur mentioned anacsthelse agents we found that the most dramatic reise of bluod serotonin occurred during the we of trilene as the level rose 10.5188 .57 and $6.348 .57 \mathrm{~g} / \mathrm{g}$. as compared io l he normal level ol 4442.5 $\mathrm{g} / \mathrm{g}$. Ether anacsithesia also resulted in a rise of the kevel of blood serotonin 10 9537.14 in the surgicul stige: white halothane did not show a significant variaton from normal and choroform resulted in a much less risce $4857.14 \mathrm{~g} / \mathrm{g}$. in the excilatory slage.

\section{DISCLSSION}

Tlac dfece of inhalation anaesthesia using ether. halothane, trilene and chloroform, on the serotonin level in blood. brain. kidneys and small intestine was experimented in (he present work using albino rabblts for anatesthesia and estimating the scrotonin level by bionsaty.

Serolonin fovel in the brain rose to d vignulieam level during anaesthesia. both at the excitatory stage and after $.0 \mathrm{~min}$. in the surgical sagge by all lour lypes of inhalation anaesthesia (Fig. IA). The peak was noled during the use of trilenc and ether being second 10 it. Rise being $198.7 \%$ wish tritene. $166 \%$ with esher while it was $160 \%$ wilh labolhane and $114 \%$ with chlorolorm.

These results coincide with those of Diàzel al (1968) who observed a rise of more than $100 \%$ with a nacshcsia in brain serolonin level. Dlay lollowed his experiment for lour hours and he noliced that the blood serotonin level during halothane anacilhesiat showed a gradual decrase white will cher it wase almosl sleady. He and orher workers \{ Bonnycastle el al 1962) suggested the rise due 10 increased symthesis rather than impaired oxidation.

The blond level of serolonin alse rose during inhalation anaesthesia. The present increase being $124.6 \%$. $101 \%$. $142 \%$ and $107 \%$ during ther. halohanc. irilene and chtorolorm anaesihesia respecively. The highest kevel noted was with irilene while halotlane showed an insignificant change (Fig. I B). 
Pable (6) ziteos or valene anoeatheaia si

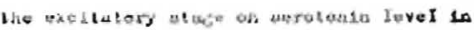
rubblta tiasun broth, blood, kidney and anati latuatre, an rint/20.

\begin{tabular}{|c|c|c|c|c|}
\hline Ia. & treis & Goad & KIdriey & Intesticu \\
\hline 1 & 490 & 5560 & J54 & 3520 \\
\hline $\bar{z}$ & 574 & 5900 & 150 & 4640 \\
\hline J & 460 & $3 \times 60$ & Ius & 3640 \\
\hline ' & 464 & $\$ 160$ & $B O$ & 3120 \\
\hline 5 & 530 & 5.40 & 130 & 3620 \\
\hline$i$ & 430 & 4600 & Iub & 3720 \\
\hline 7 & 522 & 476.1 & 125 & 4500 \\
\hline Mean & 505.71 & ', 1 the & $11 / .17$ & 3622.56 \\
\hline s. 2. & $\pm I 6.26$ & $\pm^{24}+n^{2}, \mathrm{CH}$ & $\pm 2 \cdot 2^{2}-1$ & $=143.42$ \\
\hline S. 4. & \pm 42.76 & $2^{433}$ & $=4.4$ & $=510.78$ \\
\hline 'l'. & $=12.05$ & \pm 13 & $=$. bis & 2.18 \\
\hline r. & $<0.05$ & $\left\langle u, L^{4}\right.$ & Ku. $u_{5}$ & $<4,05$ \\
\hline
\end{tabular}

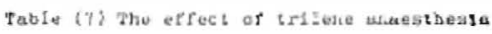
30 mise of aurieal athic on berotonit level

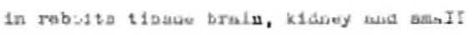
Integtine, navism.

\begin{tabular}{|c|c|c|c|c|}
\hline vo. & Zrast & wtood & Kidney & Inseatino \\
\hline$I$ & 380 & 6160 & 260 & 4920 \\
\hline 7 & 520 & 6080 & 210 & 5200 \\
\hline 3 & 660 & 6Bue & .50 & 4120 \\
\hline 1 & 530 & Losos & 215 & $44 B \bar{O}$ \\
\hline 5 & $\$ 60$ & 6560 & 220 & 3400 \\
\hline 6 & 3,65 & sebso & 230 & 4080 \\
\hline 7 & 540 & busu & 230 & 4640 \\
\hline Nown & 550 & $634 \cdot .57$ & 230.71 & 4417.14 \\
\hline S. E. & \pm 23.19 & IIsc,aI & $2^{6.94}$ & 2228.17 \\
\hline ¿. D. & \pm 61.37 & 2393.76 & $=18.35$ & $\lfloor 577.28$ \\
\hline T. & $=11.11$ & $=11.45$ & \pm 21.58 & 15.04 \\
\hline$P$. & $<0.05$ & $<0.05$ & $<0.05$ & $<0.05$ \\
\hline
\end{tabular}

Pabie (b) Zffect of otatoroforit anduatheela as the exeltakory stace on the aerotonin fevel in rubbits liasue, brain, bisad, thriay and aus II inbeatire in non/em.

\begin{tabular}{|c|c|c|c|c|}
\hline ग्र०. & bruan & Hoos & xidney & InIpketel \\
\hline 1 & $2 \%$ & 4560 & 110 & 3050 \\
\hline 2 & 320 & 5560 & 70 & 3260 \\
\hline 3 & 290 & secu & נו'י & 300. \\
\hline 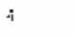 & 200 & 40010 & is & 2960 \\
\hline 5 & 205 & $4 \% t 6$ & 80 & 25,60 \\
\hline 6 & 320 & souk & 105 & JT2U \\
\hline 7 & טُنَّ & 4160 & bu & 3440 \\
\hline : sur. & 307.80 & 4557.14 & U5.?I & 2988.57 \\
\hline$\therefore=$. & $\pm 53.1 d$ & I54.74 & $26 . d$ & $\div 75.54$ \\
\hline s. B. & $=43.6 C$ & $=114.23$ & $\pm \pi 6.31$ & .200 .95 \\
\hline $\mathrm{T}$. & $:^{2}$, LU: & $=2.000$ & 24.621 & 20.639 \\
\hline$Y$. & $<0.05$ & $\left\langle u .0^{\circ}\right\rangle$ & $<0.05$ & $>0.05$ \\
\hline
\end{tabular}

rubie (19) arfoct ofentarofora maeathuata

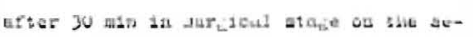

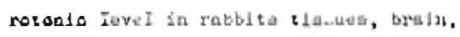

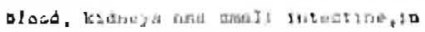

$$
\text { wotón. }
$$

\begin{tabular}{|c|c|c|c|c|}
\hline No. & Brasa & Hued & Kraney & Inteatine \\
\hline 1 & 350 & $5 B$ W & 125 & 3620 \\
\hline 2 & 336 & tut u & 150 & 3000 \\
\hline 3 & 300 & 5,560 & IIU & 3480 \\
\hline 4 & 325 & sobes & 105 & 3020 \\
\hline 5 & 305 & souls & IZU & 3204 \\
\hline$E$ & 270 & 5000 & 125 & 3650 \\
\hline 7 & 344 & stuin & $11 \%$ & 3160 \\
\hline toak & $3 \mathrm{I}$. $3 \mathrm{~A}$ & 476 & 114.213 & 3305.71 \\
\hline s. Li. & SIL. Is & $=279.46$ & \pm 2.54 & \pm 104.09 \\
\hline 5. v. & $=27.36$ & $=339.46$ & \pm 6.726 & \pm 277.56 \\
\hline I. & $=3.061$ & $=1.090$ & $\pm^{12.074}$ & 22.179 \\
\hline$\therefore$ & $<0.05$ & $>0.05$ & $<0.05$ & 30.05 \\
\hline
\end{tabular}




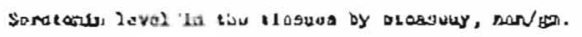

(WL: A)

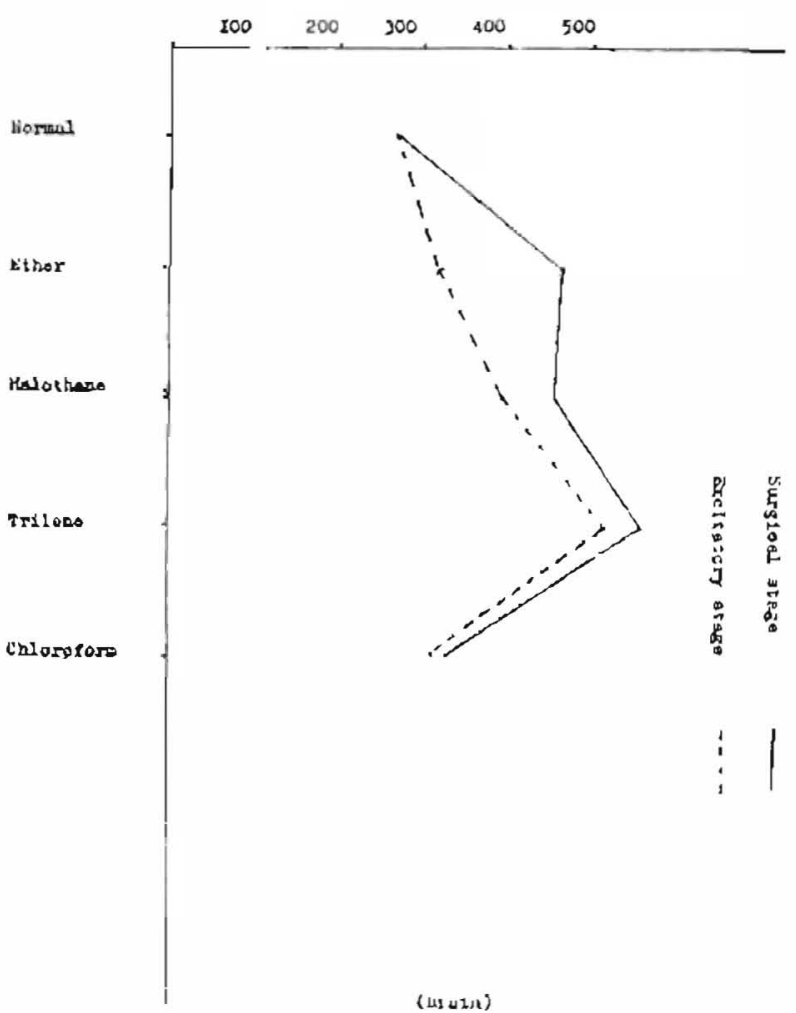

(山上⿲丶)

Berotondo level if the kianeys or rubblib gar/ga.

(128, c)

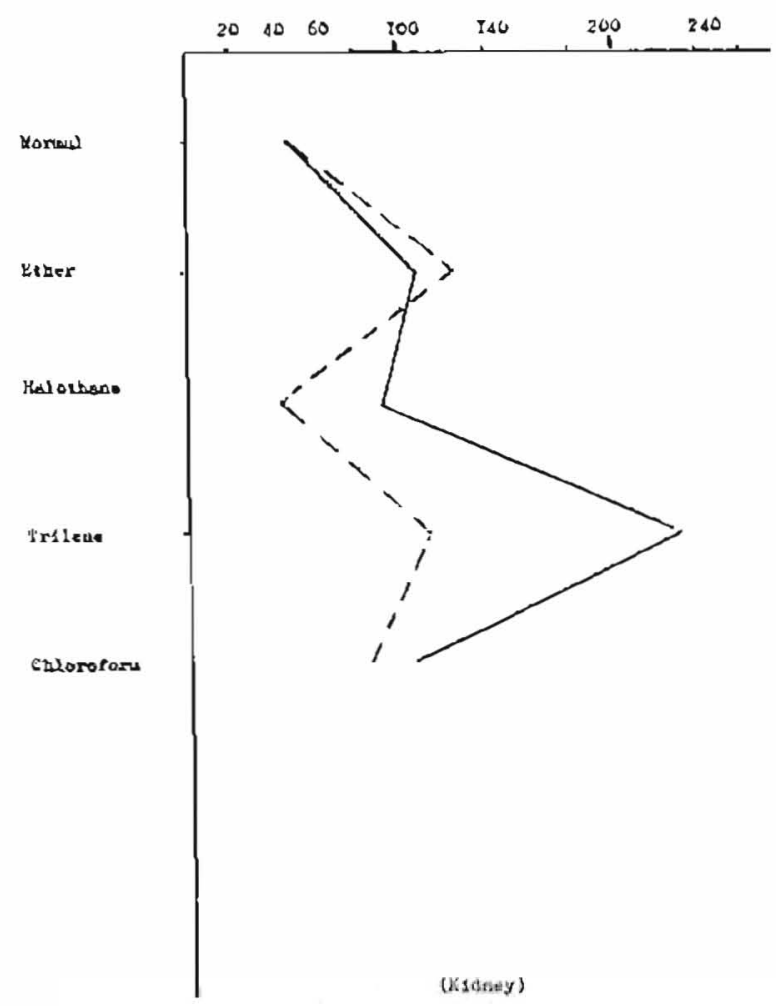

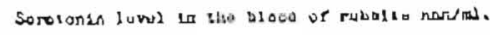

(rig, it)

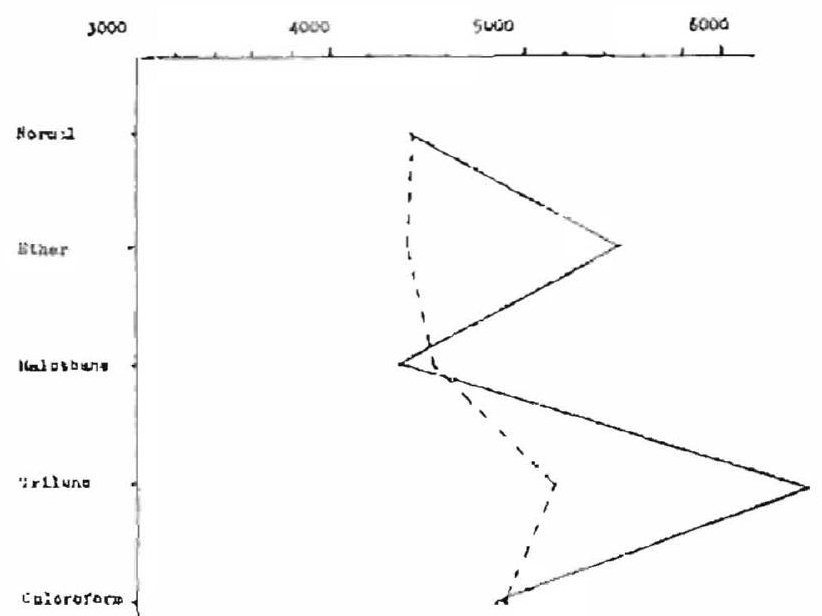

(4) uea)

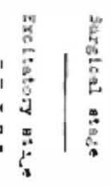

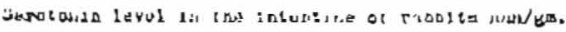

$\left(Y_{1} \cdot 0\right)$

$3000,3500,4000 \quad 1500$

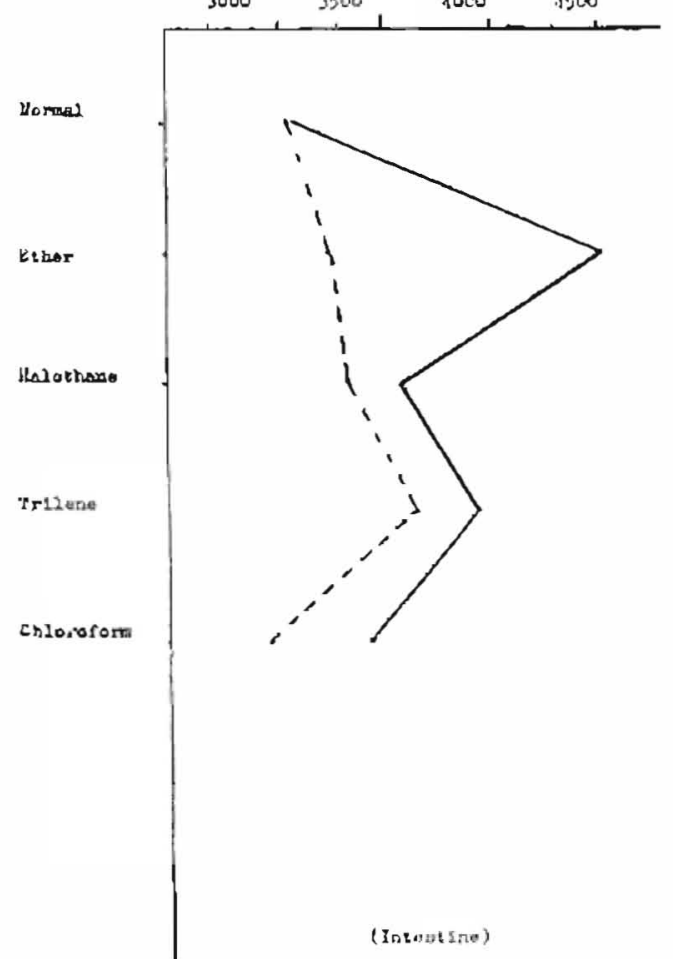

Page 140 - The Journal of IMA - Vol. 14 - October, 1982 
By' cslimating the kidney and small intestine level of scrotunin during anaesthesia the highest levels were noted during the use of irilene inhalation anaeschesia then diethyl cher (Fig. C \& D).

Tricholorocthylenc (trilene) is disepuled for its complications. Conutsions were reported Juring its use as an inhal lation anaesihesia specially with children (Coodman \& (illiman. 1976). Dysrhythmias, sinus lachycardia and somelimes heart linlure (Edwards et al 1954) are also reported to have occurred. Thin may be correlatcd with the signilicantly high kevel of selolunio in blood and brain during 11 s use as a gencrat anesthelic as observed during the present work and by other investigator's (Diaz et al. 1968 \& Bonnycastle ci al. 1962).

Dierhyl elher has no significant toxic acrion on the hearl. but the occurrence of post operative pulmonary embolism in sonu luses may be related 10 the elevalion at screronin level in the blond during anaculhesia using colver. This was obscrved by lida Sivallord (1966) who suggested the use of prophytactic anzuseroronin agents $m$ such cases (o) lower llse incidence of such complications. This may be a point 10 be considered in further studie's.

Chloroform is known 10 have many toxic cllects on the nean muscle calssing irritability. librillation and possibly heart lailure, (Hill. 1932). I is nor eommonly used as a gencral anaesthelic.

Halothane as a general inhalation anaestheric has the leats number of side reactions. It has a direct action on the vascular smooth muscles with slighe redncion of the periphereal resistance and blood pressure (1) culsch el al. 1962). This is 10 some cxlent counteracted by the action of serotonin in the blood. Halothane on the ollor hand increases the cerebral blood llow (Wooldman et al, 1965). I also results in skeletal muscle rasodilation (Black \& McArdle. 1962). Halotbane anaesthesia during the present siudy resulted in a slight rise of scrotonin levels in brain and hlood (Fig. 1. A \& B).

As regards the risc in scrolonin levels in kidneys and small intestine ubserved during inhalation anacstliesia (Fig. C \& D) this may be partly related to the vascular action of serolonin and parly duc 10 the stress condition.

\section{SUMMARY}

The serounin level in blood. brain. hidneys and small mestinc of rabbits was cxamined daring the cxcitatory and surgical stagex of inhalation anaesthesia using ether, halothane. tritene and chiorolorm. The rise was most marked with trilcne nexi wass ether and correlated with the complications expected in each case.

\section{REFERENCES}

1. Anderson. E. \& Bonnycastle, D. $(\mid \varphi(6))$ : A siudy of the central depressant action of pentobarbutat. phenobarbitone and dicthyl cther in relationship se increase in brain 5-HT, J. Pharmacol. Expt. Ther. 1.11). 1.38,

2. Black \& Mc Ardle, (1962): The effect of halothanc on the peripheral blood vessels, Anoesth. 17. 82-89.

3. Bonnycastle. D.. Bonnycastle, M. \& Anderson. F. (1962): The effect of a number of central depressan drugs upon brain 5-HT level in rats. J. Pharmatesl. Fixpl. Ther, 135. 17.

4. Cutis. D. \& Davis. R.. (1962): Pharacological studics upon neurons of the lateral geniculate nucleus of ilac cal. I. Pharmacel. Chemother. 18, 217-246.

5. Deutsh. S.. Linde. W., Dripps, R. \& Price, L. (1962): Circulatory and respiratory actions of halothane in nurmil man. Anaesthes. 23, 631-638.

o. Distr. M. Nigui. H. \& Costa. E. (1968): The effect of oxygen on the brain serotonin metabolism in rat. $1 m$. 1. Phrxiol. 214 , 5yl.

7. Edward. M. (1944): Quoted from Goodman \& Gillman (1976)

8. Guodinan. L. \& Cillman. A. (1976): The pharmacological hasis of thereapeutic. McMillan. New York \& London. Silh Ed.

9. Hill (1932): Quoled Irom Cioodman and Gillman. 1976.

10. Lida Swafford (1966): Respense of platelets and serotonin It anacslhesia and operative stress. anacsth. \& analges. $45,1.15 \%$.

I1. I.in. R. \& Yeoh. I. (I965): An Improvement on Van's slumach strip preparation for the assay of $5-\mathrm{HT} . /$. Pharmacel. 164. 192-215.

12. Nefl. H.. I ozer. N. \& Brodic, B (1967): Siudy of the Iransior of S-HTA from brain 10 plasma. $J$. Phormatw. Therap. IS世-214.

13. Orfermeiner. J. \& Ariens. E. (196(s): Serotonil. eceptors involved in its action. Arth. Inter Pharmacudinamicis. 164, 192-21.5.

14. Shcrwood. I (1954): Quoled Irom (isodman and Cillınan 11976).

15. I! urpaa. V..I. (1962): 5-1."T cument of brain and some wher organs. Experiemia, 19, 56-58.

16. Vans. I.R. (19.57): A sensitive method for the assay of serotonin. Brit. J. Pharmacol. Chemolher. 12. 344.

17. Woollman. H., Alexander, S., Cohen. P.. Chase, P.. Mciman. E. \& Marjam. Behar. (1965): Cerebral circulation of man during halothane anaesthesia. Anuevihesishog. 25. 180-191.

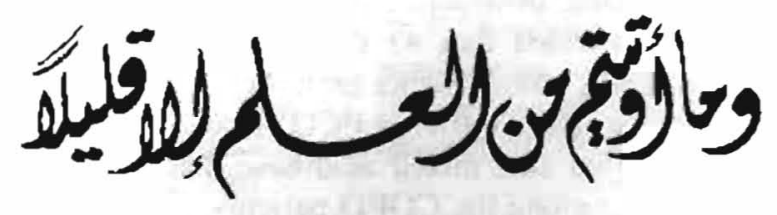

